\title{
ECONOMETRIC ANALYSIS OF CROATIA'S PROCLAIMED FOREIGN EXCHANGE RATE
}

Davor Mance, Saša Žiković, Diana Mance *

\section{Abstract}

The officially proclaimed foreign exchange policy of the Croatian National Bank (CNB) is a managed float with a discretionary right of intervention on the Croatian kuna/euro foreign exchange (FX) market in order to maintain price stability. This paper examines the validity of three monetary policy hypotheses: the stability of the nominal exchange rate, the stability of exchange rate changes, and the exchange rate to inflation pass-through effect. The CNB claims a direct FX to inflation rate pass-through channel for which we find no evidence, but we find a strong link between FX rate changes and changes in M4, as well as between M4 changes and inflation. Changes in foreign investment Granger cause changes in monetary aggregates that further Granger cause inflation. Changes in FX rate Granger cause a reaction in M4 that indirectly Granger causes a further rise in inflation. Vector Autoregression Impulse Response Functions of changes in FX rate, M1, M4, and CPI confirm the Granger causalities in the established order.

Keywords: central bank policies, monetary transmission effects, inflation targeting

JEL classification: C22, E52, E58, F42

\section{INTRODUCTION}

The Croatian National Bank (CNB) has recently changed its official policy from a free floating to a managed floating exchange regime (CNB 2013, CNB 2014). The CNB reserves the right to intervene on the currency markets and it did so more than 200 times in an 18 years period (1997-2014). The CNB has not officially determined an a priori upper or lower boundary or intervention point but it claims to maintain the stability of the kuna/euro foreign exchange $(F X)$ rate in order to meet its primary objective of price stability. A similar approach was recently also taken by the Czech National Bank (CZNB 2014).

The aim of the paper is to analyze the Croatian kuna/euro foreign exchange policy (FX policy) using

\section{* Davor Mance, MA}

Assistant

University of Rijeka, Faculty of Economics davor.mance@efri.hr

Saša Žiković, PhD

Associate Professor

University of Rijeka, Faculty of Economics

szikovic@efri.hr

\section{Diana Mance, PhD}

Senior Assistant

University of Rijeka, School of Medicine

diana.mance@uniri.hr 
an econometric approach. The three hypotheses tested in this paper and based upon CNB statements on their web pages are: (1) 'the CNB does not predetermine the lower and upper level of the kuna exchange rate it is committed to defend (the upper and lower intervention point)'; (2) 'the CNB participates in foreign exchange market transactions in order to prevent excessive exchange rate fluctuations in both directions', and (3) 'the CNB maintains the stability of the kuna/ euro exchange rate in order to meet its primary objective of maintaining price stability' (CNB 2014). The stated reason for the proclaimed CNB policy is a presumed fast transmission channel between inflationary expectations and exchange rate changes (CNB 2014). This inflation pass-through effect is important as it prevents the exchange-rate policy from being an effective policy tool for employment and GDP growth. This is the reason why we analyze the statistical relationships and Granger causalities between Foreign Investments (FI), the foreign exchange (FX) rate and the consumer price index (CPI) via transmission monetary aggregates $\mathrm{M} 1$ and $\mathrm{M} 4$.

The paper continues with a literature review with comments, followed by an explanation of our comprehensive data set and methodology. In the results and discussion section, statistical tests are consequently applied and commented on.

\section{LITERATURE REVIEW}

During the last 15 years several empirical studies on monetary transmission channels in Croatia have come to different conclusions. The presumed inability to model the primary FX rate time series because of its non-stationarity, non-normality, heteroscedasticity, and the presence of frequent structural breaks in the time series has motivated several other authors to model the FX returns instead, and to pursue various ARCH (Autoregressive Conditional Heteroscedasticity), TAR (Threshold Autoregression) and VAR (Vector Autoregression) approaches (Posedel 2006, Tica and Posedel 2009, Erjavec et al. 2012). Earlier exchange rate - inflation pass-through research did not come to converging results regarding the endogeneity of the exchange and inflation rate (Choudhri and Hakura 2001, Cukierman, Miller, and Neyapti 2002, Devereux and Engel 2003, Gagnon and Ihrig 2004, Mihaljek and Klau 2008). In regard to Croatia, Stučka (2004) found statistically significant J-curve effects with subsequent implications on investment, production, and international trade, with the latter having an influence on inflation. These are indirect effects that, according to the envelopment theory, should be disregarded in the direct assessment of FX - inflation pass-through effects. Subsequent research shows that the passthrough effect declines with increasing monetary stability and decreasing inflation (Mihaljek and Klau 2008). Monetary stability has, in this regard, a psychological memory effect and a non-linear relationship.

For a small open economy such as Croatia, credit and liability euroization reduces the efficiency of the FX rate as a shock absorber, such that the positive effects of free floating are easily mitigated against (Devereux and Lane 2003). The question of the "fear of floating" (Calvo and Reinhart 2000) may be countered by the question of the "fear of commitment" in an environment involving the future obligation of every EU country (except UK and Sweden) to eventually join the EMU. The question of "either fix or float" and suboptimal intermediary policies has been discussed at great length (Mundell 1961, Friedman and Mundell 2001, Buiter and Grafe 2002). As Friedman and Mundell (2001) concluded, intermediary solutions are suboptimal. With credit and liability euroization constraints present in Croatia, it might have been optimal in the past to have a formal currency board as in Bosnia and Herzegovina and Montenegro, or, fast-forwarding to the present day, beneficial in the short run to make an earlier firm commitment to the Economic and Monetary Union. This may be the principal reason for the change of the FX policy description on the official CNB web site from free float to managed float. The authors' aim was to put this label to comprehensive econometric testing.

\section{DATA AND METHODOLOGY}

The time series of kuna/euro FX rate consists of monthly observations covering the period from January 1997 to April 2014 (CNB 2014). Consumer price index $(\mathrm{CPI})$, foreign investment $(\mathrm{FI})$, and $\mathrm{M} 1$ and M4 monetary aggregates data were comprehensively available only on a quarterly basis from Q4 of 2000 to Q4 of 2013 (CNB 2014).

To model the FX time series, a Box-Jenkins methodology with a truncated Fourier series approach was used. Let $y_{t}$ be time series with $t=1, \ldots, N$, where $N$ is length of time series. In order to determine the seasonal variations and trend, the time series is divided into two components:

$$
y_{t}=\chi_{t}+Y_{t}
$$

where $Y_{t}$ is a stochastic irregular component and $\chi_{t}$ is a deterministic periodic function of the truncated Fourier series form: 


$$
\chi_{t}=c_{1}+c_{2} \cdot t+c_{3} \cdot \cos \left(\frac{2 \pi}{T} \cdot t-c_{4}\right)
$$

$c_{1}$ is the mean, $c_{2}$ is the linear trend, $c_{3}$ is the seasonality amplitude, $c_{4}$ is the phase correction, $T$ is the period and $t$ is time in months.

To model the stochastic component $Y_{t}$ in the equation (1), ARIMA modelling of time series is used (Box, Jenkins, and Reinsel 2008). If $Y_{t}$ is stationary one can construct a $p$-order autoregressive (AR) model (3) and/ or $q$-order moving average (MA) model (4):

$$
\begin{aligned}
& Y_{t}=\sum_{i=1}^{p} \Phi_{i} Y_{t-i}+\varepsilon_{t} \\
& Y_{t}=\varepsilon_{t}-\sum_{i=1}^{q} \theta_{i} \varepsilon_{t-i}
\end{aligned}
$$

In AR models, the current value of the process is expressed as a finite, linear aggregate of previous values of the process $Y_{t-i}$ and white noise $\varepsilon_{t}$. In MA models, $Y_{t}$ linearly depends on finite number $q$ of previous random shocks $\varepsilon_{t-i}$. When (3) and (4) are both included in one model, one gets a mixed autoregressive-moving average (ARMA) model. If $Y_{t}$ is nonstationary, one can construct an autoregressive-integrated moving average (ARIMA) model of order $(p, d, q)$, where $d$ is the $d^{\text {th }}$ difference of the process after which stationarity is achieved. ARIMA model fitting was performed with a three-stage Box-Jenkins technique: identification, estimation and verification (Maddala 2001). During the identification phase, the main tool was a visual analysis of the autocorrelation function (ACF) and partial autocorrelation function (PACF) (Enders 2010).

To test the assumption that one series may have a delayed response to the other series the cross-correlation function (CCF) was analyzed. Autocorrelation and cross-correlation coefficients are considered significant within $\pm 1.96 / \sqrt{N}$ the bounds.

The time series stationarity may be influenced by structural breaks since structural breaks in the data can change the value of its mean, or the vector of its movement. To identify structural breaks the ZivotAndrews test was used (Zivot and Andrews 1992). To test for stationarity in the time series we use the Augmented Dickey-Fuller test (ADF).

To identify other transmission channels, the lags and leads between the variables, and to simultaneously avoid spurious correlations, the $\mathrm{CPI}, \mathrm{FI}, \mathrm{M} 1$ and M4 $1^{\text {st }}$ differences (differences assured stationarity) are Granger tested and the speed of the pass-through effects is tested with impulse response functions. The
Granger test is a standard bivariate regression:

$$
\begin{aligned}
& y_{t}=\alpha_{0}+\alpha_{1} y_{t-1}+\cdots+\alpha_{l} y_{t-l} \\
& +\beta_{1} x_{t-1}+\cdots+\beta_{l} x_{t-l}+\varepsilon_{t} \\
& x_{t}=\alpha_{0}+\alpha_{1} x_{t-1}+\cdots+\alpha_{l} y_{t-l} \\
& +\beta_{1} y_{t-1}+\cdots+\beta_{l} x_{t-l}+\omega_{t}
\end{aligned}
$$

for all pairs of $x_{t}, y_{t}$ series in the group (Granger 1969). The strength of causation is reported according to the F-statistics based on the Wald statistics for the joint hypothesis: $\beta_{1}=\beta_{2}=\cdots=\beta_{l}=0$.

Nonstationary variables are tested for cointegrations. If two nonstationary time series are cointegrated with some stationary time series, a causal relationship may be assumed and further tested with a Vector Error Correction (VEC) model (Engle and Granger 1987). If the time series are not cointegrated, a Vector Autoregression (VAR) approach is considered (Johansen 1991).

Statistical tests and estimation of the model coefficients was performed by the E-Views 7.2 statistical package.

\section{RESULTS AND DISCUSSION}

The assessment of the correct label on the FX regime of a country requires a careful analysis of its time series, and testing whether the stochastic process of the exchange rate values follows a mean reverting process in response to central bank interventions. For this purpose, we use Box-Jenkins time-series analysis, Granger causality and Johansen cointegration tests (Box, Jenkins, and Reinsel 2008, Granger 1969, Johansen 1991). To the authors' knowledge the autoregressive (AR) kuna/euro FX time series has for the first time been augmented by a truncated Fourier series.

\section{Stability testing and Box-Jenkins ARIMA modelling}

For the monthly FX series for the period January 1997-April 2014 the Zivot-Andrews test found an endogenous structural break in level and trend in September 1998 (Fig. 1). Therefore, the observations can be grouped around two separate targets in level and time: the period before and after Sep 1998. The structural break in level and trend shown in Figure 1 can be attributed mainly to the change in statistical methodology and the introduction of the Value 


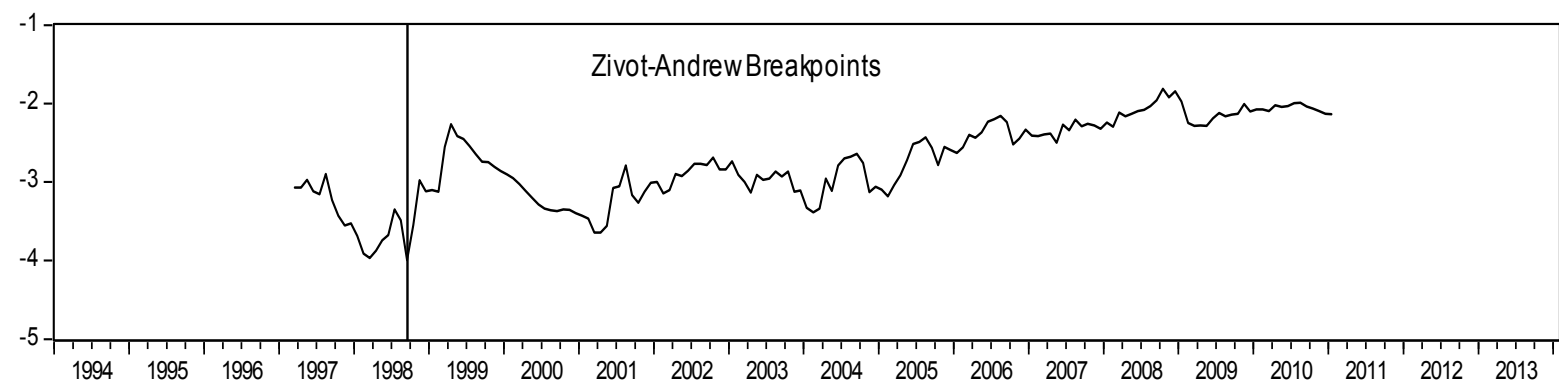

Figure 1: Zivot-Andrews structural break test. Data source: CNB 2014, calculation: E-Views 7.2.

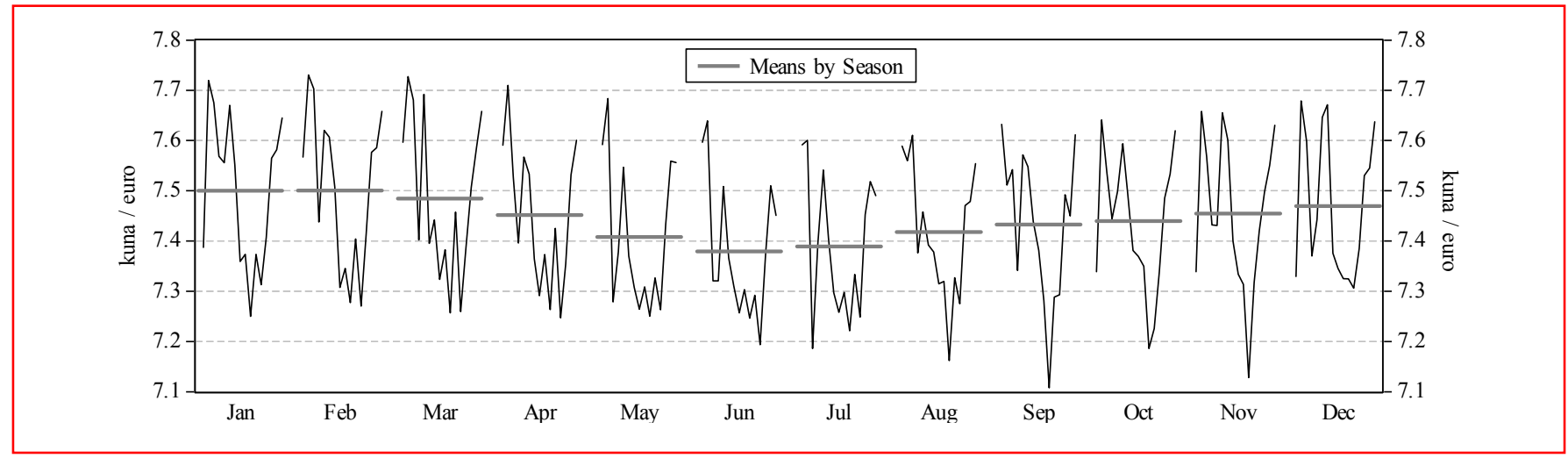

Figure 2: Kuna/euro FX rate means by season. Data source: CNB 2014, calculation: E-Views 7.2.

Added Tax in 1998. After Sep 1998 the FX rate is fairly constant with a mean of 7.44 and a coefficient of variation of $1.9 \%$. Further calculations and analysis are restricted to the period between October 1998 and April 2014.

When analysing seasonal averages of the kuna/ euro FX rate it can be seen that they exhibit a regular behaviour with maximum values in winter months, and minimum values in summer months (Fig. 2). Such seasonal behaviour can be explained by large tourism receipts, an important driver for the Croatian economy, peaking in summer months and euro denominated loan repayments peaking in winter months. Due to this seasonal behaviour the dynamics of the monthly kuna/euro FX rate can be described by (1).

Residuals remaining after the removal of the periodic component were tested for stationarity. The ADF test showed that the series is stationary in level and trend. The ACF of the residuals has dropped below the statistically significant level after approximately two years. The series is characterized by a drop in the PACF after only one month, without any significant reverse effect. This behaviour implies an $\operatorname{ARIMA}(1,0,0)$ i.e. $\operatorname{AR}(1)$ process. The final model of the dynamics of the monthly kuna/euro FX rate is represented by the following equation:

$y_{t}=7.468+0.052 \cdot \cos \left(\frac{2 \pi}{12} \cdot t+1.385\right)+0.937 \cdot y_{t-1}+\varepsilon_{t}$

$R^{2}=0.885$

Parameter coefficients, standard errors as well as standard statistical tests and diagnostic measures are given in Table 1 . The linear trend is statistically not significant $(p>0.1)$.

Table 1: Parameter values of the HRK/EUR FX rate time-series model.

\begin{tabular}{|lllcl|} 
Variable & Coefficient & Std. Error & t-Statistic & Prob. \\
\hline C(1) & 7.468 & 0.057 & 130.201 & 0.000 \\
C(3) & 0.052 & 0.009 & 5.271 & 0.000 \\
C(4) & -1.385 & 0.188 & -7.365 & 0.000 \\
AR(1) & 0.937 & 0.026 & 35.685 & 0.000 \\
\hline R-squared & 0.885 & Mean dependent var & 7.444 \\
Adjusted R-squared & 0.884 & S.D. dependent var & 0.14 \\
S.E. of regression & 0.048 & Akaike info criterion & -3.221 \\
Sum squared resid & 0.412 & Schwarz criterion & -3.151 \\
Log likelihood & 300.283 & Hannan-Quinn criter. & -3.192 \\
F-statistic & 463.475 & Durbin-Watson stat & 1.552 \\
\hline
\end{tabular}

Data source: CNB 2014, calculation: E-Views 7.2. 


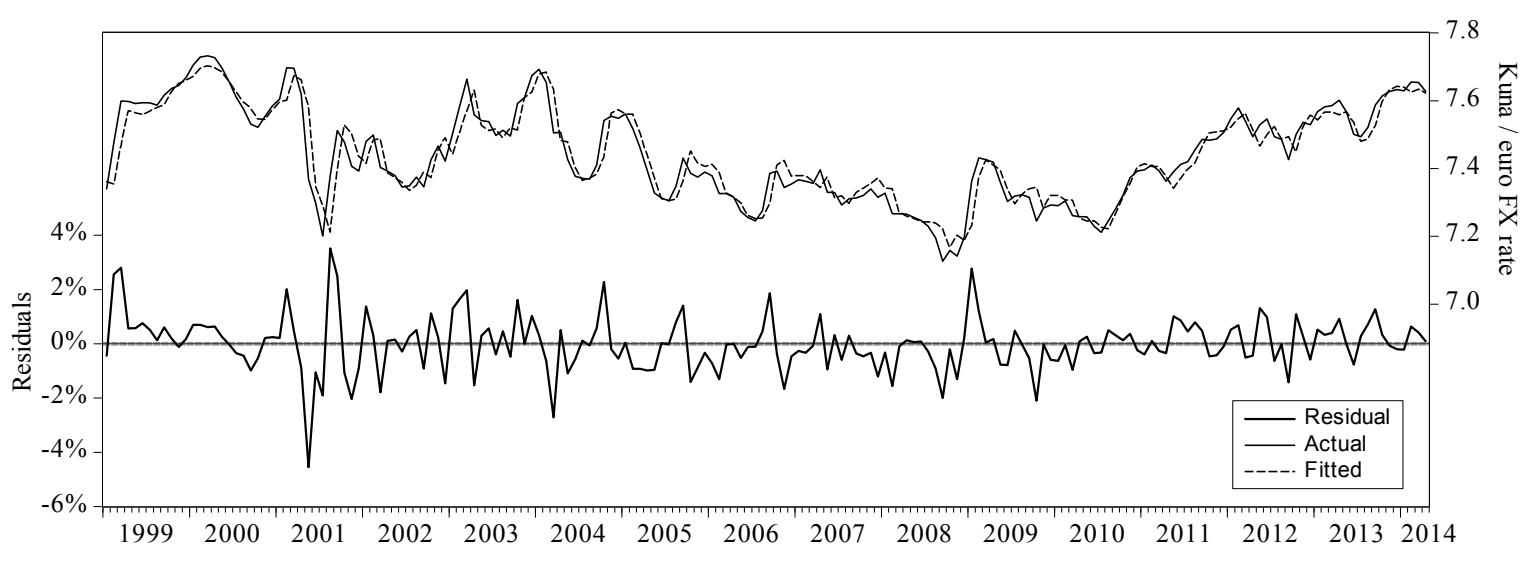

Figure 3: HRK/EUR FX rate series, model (periodic and AR(1) fit) and residuals. Data source: CNB 2014, calculation: E-Views 7.2.

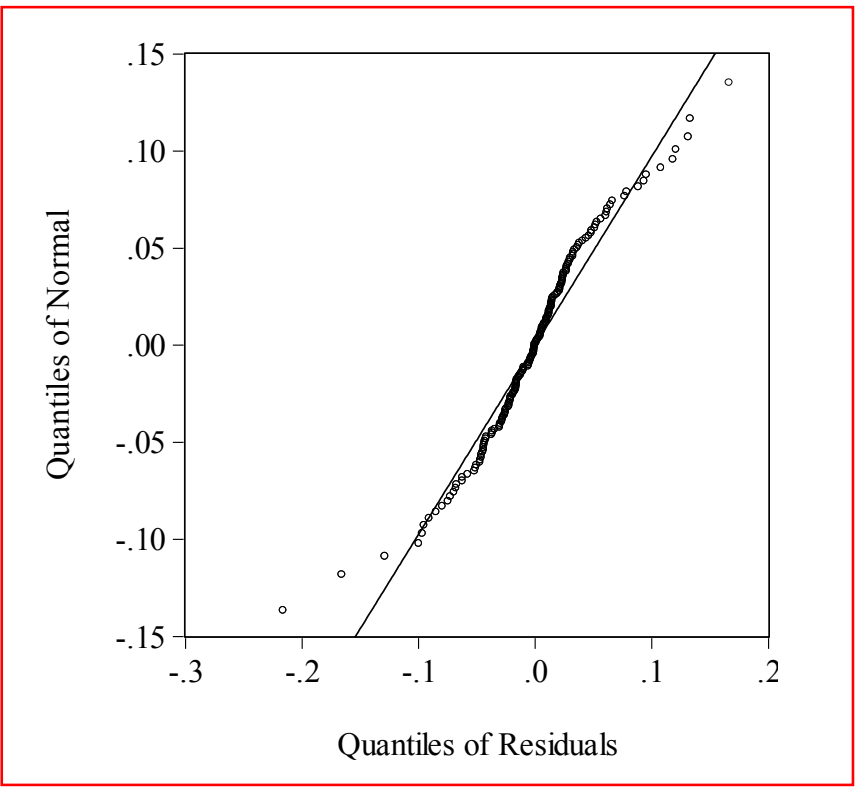

Figure 4a: Quantiles of residuals. Calculation: E-Views 7.2.

The relationship between the original time series and the model is shown in Fig. 3. The residuals are homoscedastic (White test: $F$-statistic $=1.166, p=0.322$; Harvey test: $F$-statistic $=1.732, p=0.145$ ).

The theoretical and symmetry quantile-quantile plots in Fig. 4a and 4b show a close to normal distribution of the residuals.

\section{Testing For Transfer Mechanisms}

Testing for the FX rate/rate of inflation relationships (correlation, cross-correlation, and Granger causality) provides insight on the transfer mechanisms between the two. The correlation between FX rate and inflation is $R=-0.11$ ( $p>0.01$ ), leading to the conclusion

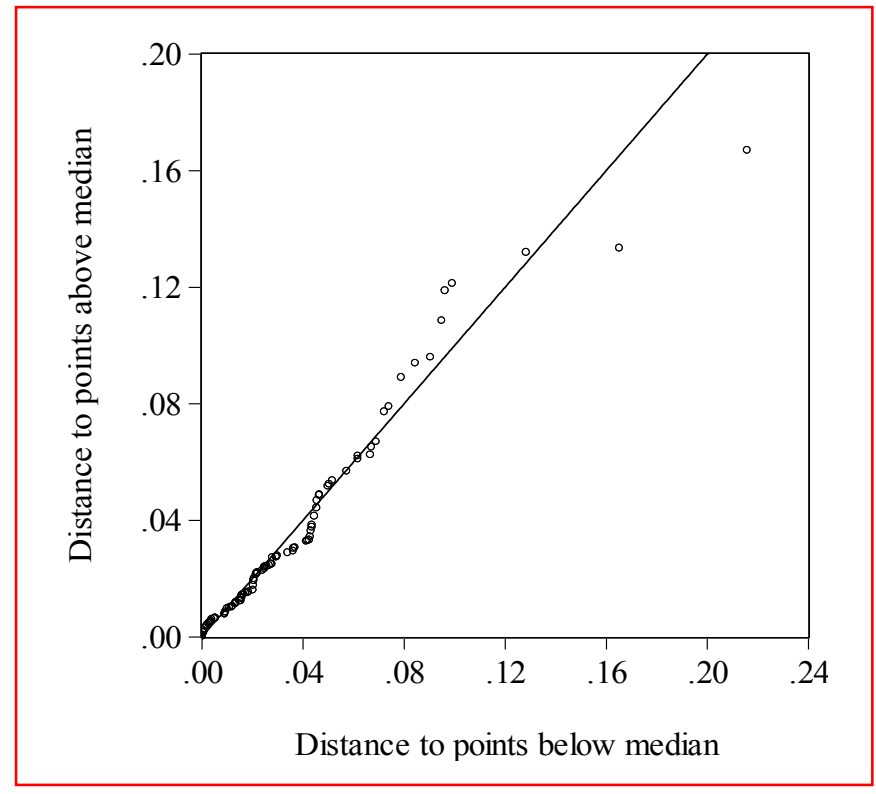

Figure 4b: Residuals distances from median. Calculation: E-Views 7.2.

that the absolute values of FX rate and inflation rate are not correlated. The CCF of FX rate and inflation chain indices is also not statistically significant (all CCF coefficients were smaller than 0.15).

The period of 2001-2008 saw a stable kuna/euro FX rate (Fig. 3), and as can be seen in Fig. 5, a fine upward slope of continuously compounded quarterly exponential growth of $8 \%$ in $\mathrm{FI}\left(R^{2}=0.97\right)$, cumulatively $800 \%$ between Q4/2000 and Q4/2007, and a 30\% increase in CPI (CBD 2014), coming to a halt after the outbreak of the financial crisis in 2008. Looked at from this perspective, the crisis deprived Croatia of significant growth in FI and GDP. Since Croatia was and still is in an implicit currency peg regime, a stop in $\mathrm{FI}$ growth rates also Granger caused a stop in growth rates of monetary aggregates (Fig. 5). 


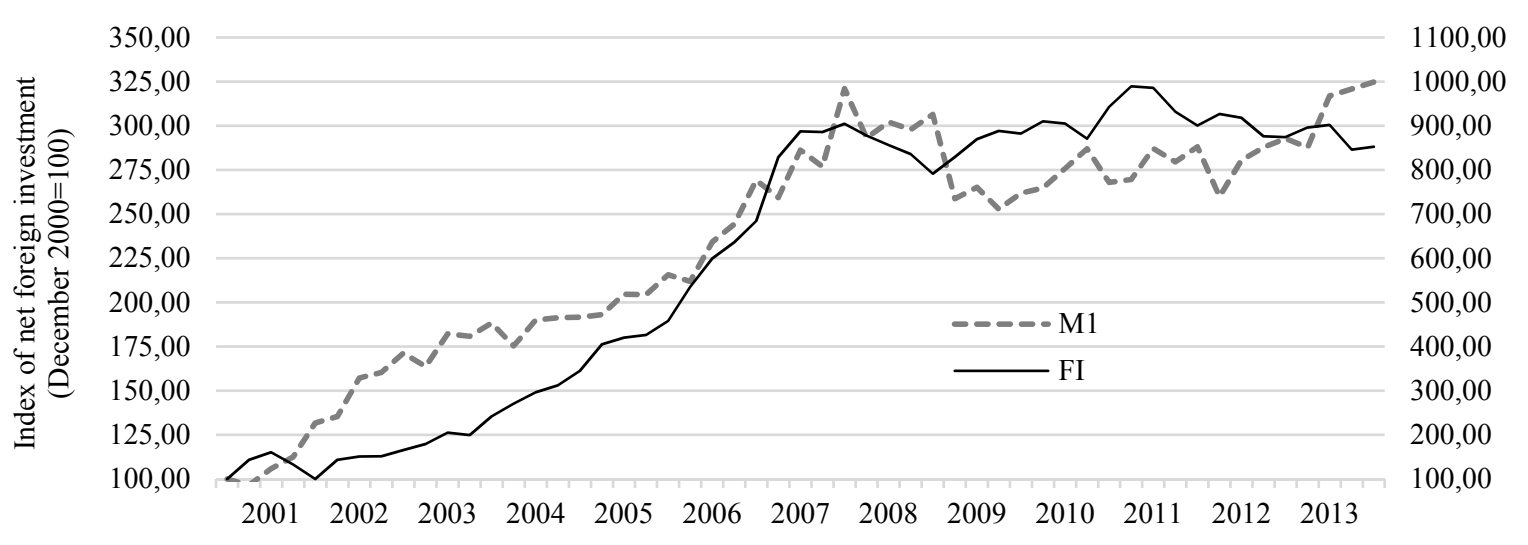

Figure 5: Levels of net foreign investments (FI) and monetary aggregate M1. Data source: CBD 2014, CNB 2014, own calculation.

Table 2 shows the pairwise Granger causality tests on quarterly data (data was $1^{\text {st }}$ differentiated to achieve stationarity) of several factors conjecturing causal relationships in an inflation pass-through effect. The reason for using quarterly data is the availability of foreign investment time series in quarterly data, as well as because quarterly data assured a stronger expression of seasonality in the data, thus creating a better wave signal and improving the measurement of impulses in impulse response functions.

The analysis of quarterly time series data confirmed no statistically significant direct transmission channel between the change in the FX rate and inflation (Table 2). Economic theory provides us with different

Table 2: Granger Causality Tests.

\begin{tabular}{lccc} 
Null Hypothesis: & Obs. & F-Statistic & Prob. \\
D(FX) does not Granger Cause D(CPI) & 50 & 1.025 & 0.367 \\
D(CPI) does not Granger Cause D(FX) & & 0.09 & 0.911 \\
D(FX) does not Granger Cause D(FX) & 50 & 2.646 & 0.082 \\
D(CPI) does not Granger Cause D(FI) & & 2.342 & 0.108 \\
D(M1) does not Granger Cause D(CPI) & 50 & 20.098 & 0.000 \\
D(CPI) does not Granger Cause D(M1) & & 0.357 & 0.702 \\
D(M4) does not Granger Cause D(CPI) & 50 & 7.709 & 0.001 \\
D(CPI) does not Granger Cause D(M4) & & 1.570 & 0.219 \\
D(FI) does not Granger Cause D(FX) & 50 & 2.603 & 0.085 \\
D(FX) does not Granger Cause D(FI) & & 2.869 & 0.067 \\
D(M1) does not Granger Cause D(FX) & 50 & 1.557 & 0.222 \\
D(FX) does not Granger Cause D(M1) & & 3.111 & 0.054 \\
D(M4) does not Granger Cause D(FX) & 50 & 0.685 & 0.509 \\
D(FX) does not Granger Cause D(M4) & & 8.248 & 0.001 \\
D(M1) does not Granger Cause D(FI) & 50 & 1.486 & 0.237 \\
D(FI) does not Granger Cause D(M1) & & 6.279 & 0.004 \\
D(M4) does not Granger Cause D(FI) & 50 & 6.080 & 0.005 \\
D(FI) does not Granger Cause D(M4) & & 6.712 & 0.003 \\
D(M4) does not Granger Cause D(M1) & 50 & 1.636 & 0.206 \\
D(M1) does not Granger Cause D(M4) & & 1.749 & 0.186 \\
INTERVENTION does not Granger Cause D(FX) & 231 & 5.438 & 0.000 \\
D(FX) does not Granger Cause INTERVENTION & & 2.380 & 0.030 \\
\hline
\end{tabular}

$\mathrm{FI}=$ Foreign Investment; $\mathrm{CPI}=$ Consumer Price Index; FX=FX rate; M1\&M4=Monetary Aggregates; Prefix D denotes first difference of data. Data source: CNB 2014, calculation: E-Views 7.2 
determinants of inflation sources. Nevertheless "...inflation is always and everywhere a monetary phenomenon" (Friedman 1963). This statement was confirmed for the example of CNB monetary policy by testing the growth of the monetary aggregates M1 and M4 in regard to the change in the CPI (Table 2).

There is Granger causation between the highly correlated variables of M4 changes and FI changes, between the changes in $\mathrm{M} 4$ and inflation (changes in (PI), as well as between FX rate changes and changes in M4. The strongest Granger causation of inflation comes from changes in the monetary aggregate M1 ( $F$-statistic $=20.1, p<0001$ ). Strong Granger causation of changes in monetary aggregates from $\mathrm{Fl}$, with the FX rate staying relatively fixed, is a confirmation of an effective currency peg.

\section{Is it fixed, or does it float?}

The Mundell's Impossible trinity theory states that with free capital flows and stable exchange rates, a country cannot keep its monetary policy sovereign (Mundell 1961). The dilemma is between fixing and floating. The question of "fear of floating" (Calvo and Reinhart 2000) is countered by the question of "fear of commitment". Intermediary policies are unstable and for a small open economy lead to untrustworthy monetary policies (Buiter and Grafe 2002) the productive sector cannot commit to with long-term plans. In the case of corner solutions (fix or float) the markets are given unambiguous information about the government's reactions to shocks and about the risks from

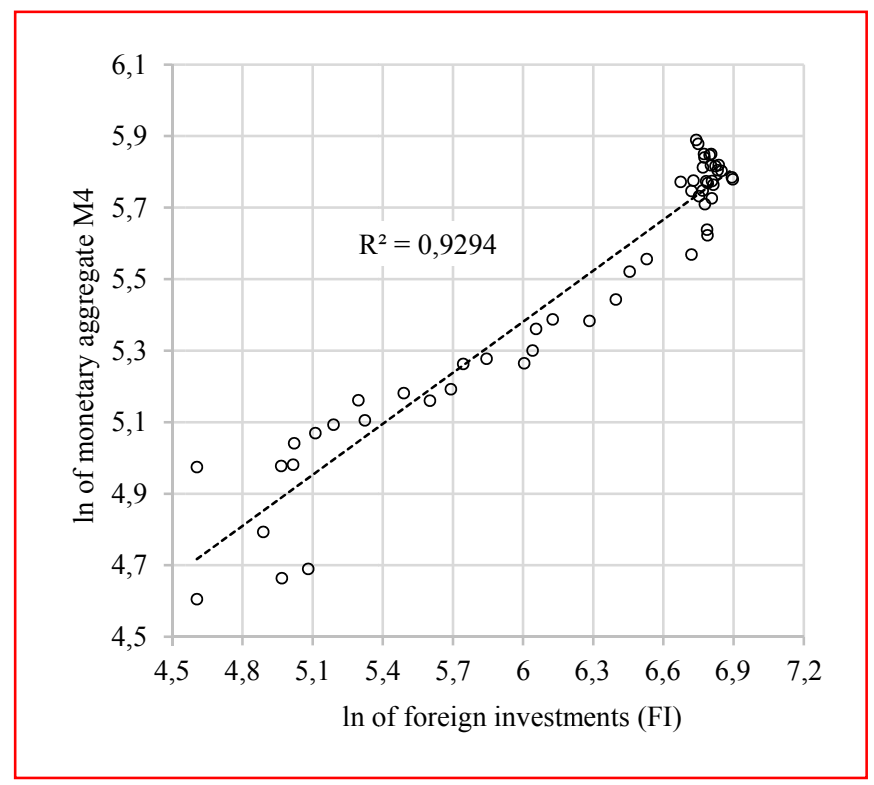

Figure 6a: Correlation between FI and M4. Data source: CBD 2014, CNB 2014, own calculation. non-hedged foreign exchange positions (Schadler et al. 2004). A floating rate gives no particular advantage over the hard peg. It gives no real monetary policy independence in an environment of high exchange rate/inflation rate pass-through velocity. It is not an automatic shock absorber in a high liability euroization environment and does not discourage unhedged currency exposures because the financial derivatives markets are undeveloped. The elimination of currency risks enhances policy credibility and stimulates Foreign Investments (FI).

The CNB has obviously discarded its own monetary policy sovereignty. The present low inflation rates are more a result of a stop in FI inflows than of FX policy (Fig. 5), and the presence of an intermediary monetary transmission channel between the two (Table 2).

Figures $6 \mathrm{a}$ and $6 \mathrm{~b}$ show the correlation between $\ln (\mathrm{FI})$ and $\ln (\mathrm{M} 4)$, and between $\ln (\mathrm{M} 4)$ and $\ln (\mathrm{CPI})$ in Croatia. Furthermore, they depict a possible transmission mechanism of inflation in Croatia. The mechanism starts with a pegged $\mathrm{FX}$ rate. Foreign investments get absorbed by the monetary aggregates $\mathrm{M} 1$ and $\mathrm{M} 4$ (sterilized or not), which further increase the CPI.

There are actually no legal requirements for the CNB to use a double anchor for monetary stability. The CNB has the foremost constitutional obligation to preserve price stability. The CNB claims to "maintain the stability of the kuna/euro FX rate in order to meet its primary objective of maintaining price stability" (CNB 2014). As our econometric analysis shows, the best way to preserve price stability is by controlling monetary aggregates. Other intermediary goals may be pursued only if they are commensurate with the

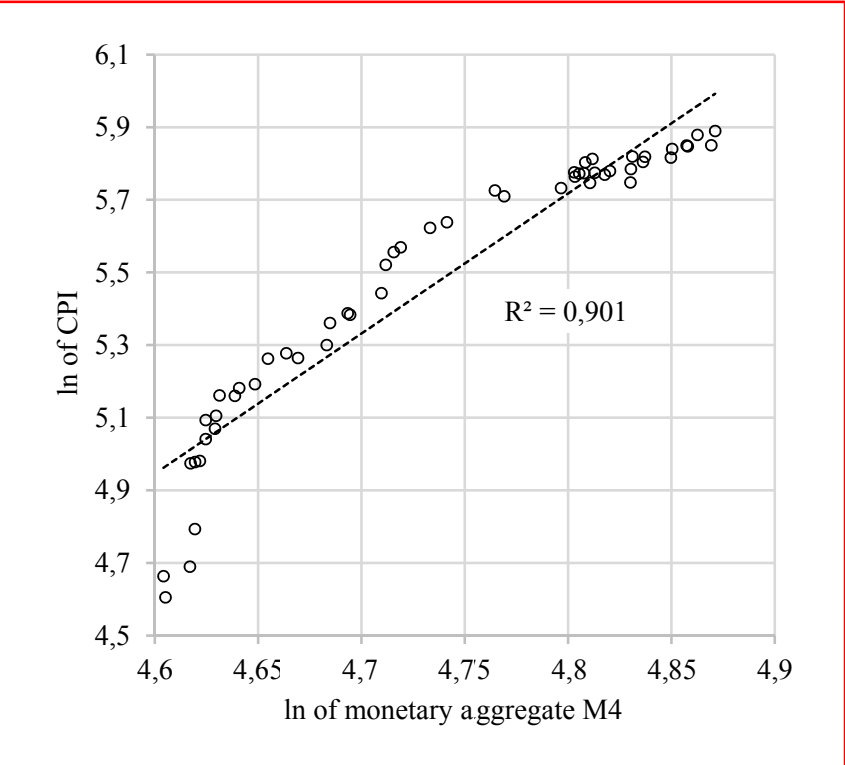

Figure 6b: Correlation between M4 and CPI. Data source: CBD 2014, CNB 2014, own calculation. 
primary goal and this is the case under the absence of strong Balassa-Samuelson and Baumol-Bowen effects. FX rate stability guarantees $\mathrm{CPI}$ stability indirectly. There is Granger causality between the changes in $\mathrm{Fl}$, and inflation through the monetary M1 and M4 transmission channel. With the FX pegged to the euro, and Croatia's recession eventually coming to an end, the pressure on inflation might increase, so the timing of this change in the proclaimed CNB FX policy actually represents a positive signal towards EMU entry. This evolution comes as no surprise since Croatia has the highest level of euroization of all CEEC's and practically no ability to conduct a sovereign monetary policy. With nothing to lose, a firmer commitment may bring some reduction in risks and interest rates.

At the core of the question is the problem of heterodox goals and the effectiveness of the pass-through effect between FX returns and inflation. The passthrough effect measures the response of inflation to exchange rate changes. The smaller, more open and more internationally integrated an economy, the larger the pass-through effect should be. The efficiency of the exchange rate as an adjustment mechanism during the EMU convergence process depends highly on the pass-through effect (Devereux and Engel 2003). A high pass-through coefficient means also a high crosscorrelation between the FX rate changes and inflation, and reduced adjustment policy effectiveness. Such high pass-through requires constant $\mathrm{FX}$ interventions.

Table 2 shows the results of testing the CNB FX interventions and FX moments for mutual Granger causation as one possible sign of CNB effectiveness in its implicit currency peg without an explicit currency board. It shall be reminded once again, that the CNB interventions amount to less than $3 \%$ of the total kuna/ euro market volume (CNB 2014). The Granger causality test clearly shows that the CNB FX interventions are effective since they do Granger cause the FX rate to change $(p<0.001)$. Even more interestingly, there is Granger causation going from FX rate change to intervention ( $p=0.03$ ), which leads to the conjecture that CNB interventions are based on observed developments in FX markets and are not pre-emptive (Mohanty and Berger 2013). A cross-correlation test of $\mathrm{FX}$ rates and $\mathrm{FX}$ interventions has shown a disappearance of the effect after two quarters.

We test if the FX rate is changed in the right direction. In Fig. 7 a correct slope of the regression can be seen, but there are too many shots missing their mark. Nevertheless, the kuna/euro FX rate is stable in the long run and without a statistically significant trend, showing a successful FX intermediate policy goal.

Johansen co-integrations tests between FX rate (stationary), and combinations of M1, M4, and CPI (nonstationary) give no cointegrating vectors, requiring the use of a VAR instead of a VEC model. We tested the VAR Impulse Response Functions of relative changes in the FX rate, M1, M4, and CPI to test for the inflation pass-through. Figure 8 shows the impulse response functions of a dependent variable to a shock of a $1 \sigma$ change in the independent variable. All variables are differenced for stationarity and normalized. The time lag is shown in months.

Fig. 8 shows the expected response result from inflation to a $1 \sigma$ shock in the FX rate, and an expected response result from inflation to a $1 \sigma$ shock in the change of M4. The response from the $M 4$ to a $1 \sigma$ shock in the change of the FX rate is also as expected. It overshoots at first, then backlashes, but then normalizes after four months. It may be concluded that the transmission channel goes from the FX rate, via the M4 monetary aggregate to inflation. The response of the change in the FX rate to a $1 \sigma$ shock in the rate of inflation representing the central bank intervention is

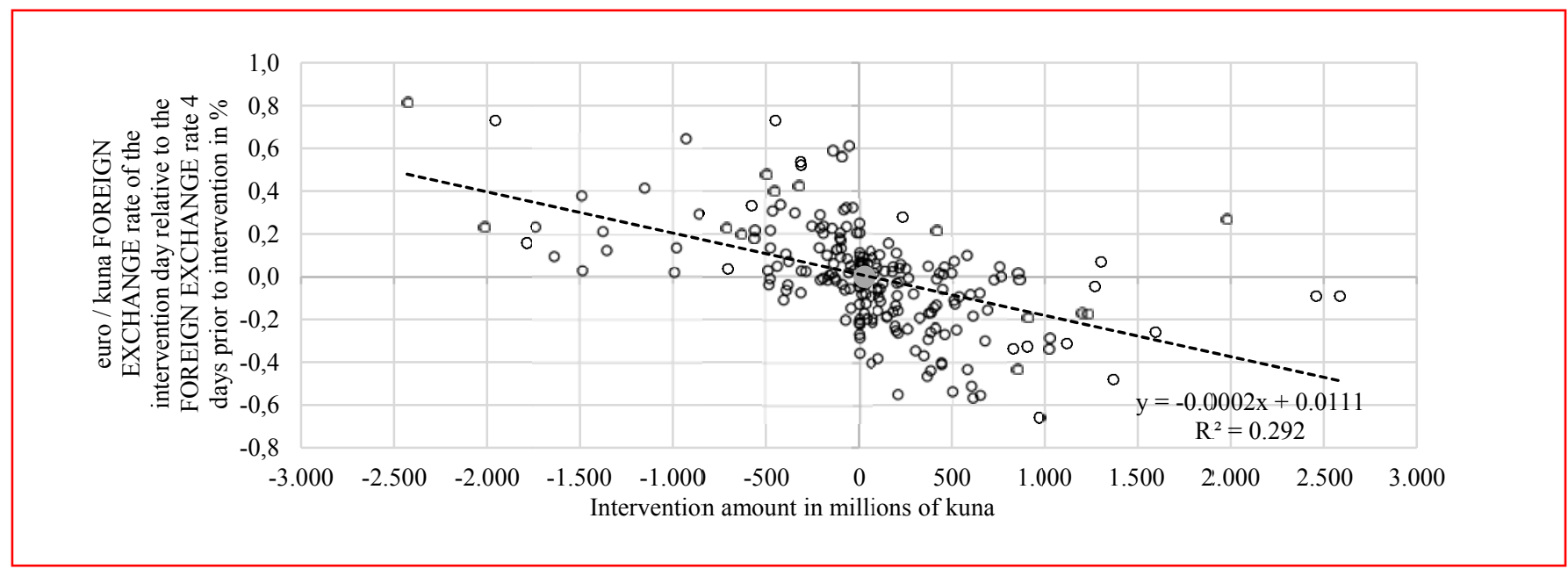

Figure 7: Euro/kuna FX rate changes as a consequence of FX interventions. Data source: CNB 2014, own representation. 
Response of $\mathrm{D}(\mathrm{CPI})$ to $\mathrm{D}(\mathrm{FXRATE})$

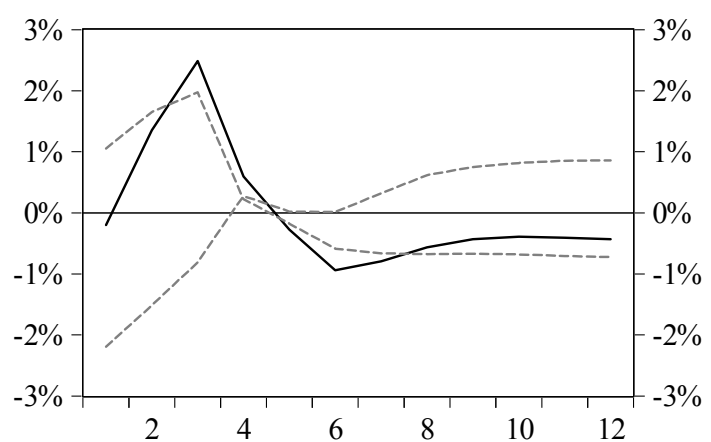

Response of $\mathrm{D}(\mathrm{CPI})$ to $\mathrm{D}(\mathrm{M} 4)$

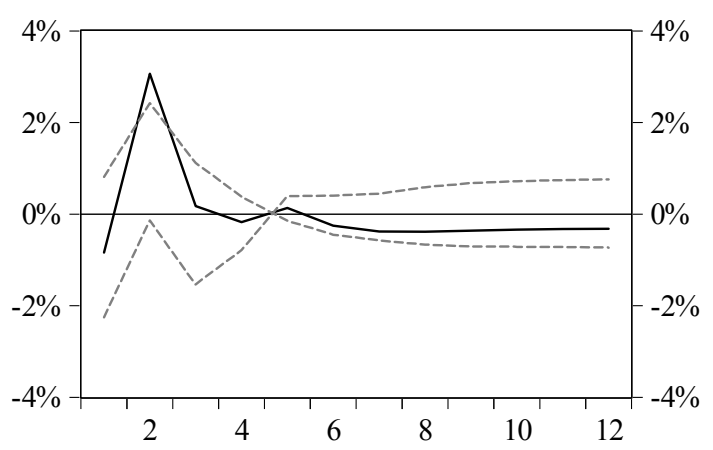

Response of D(M4) to D(FXRATE)

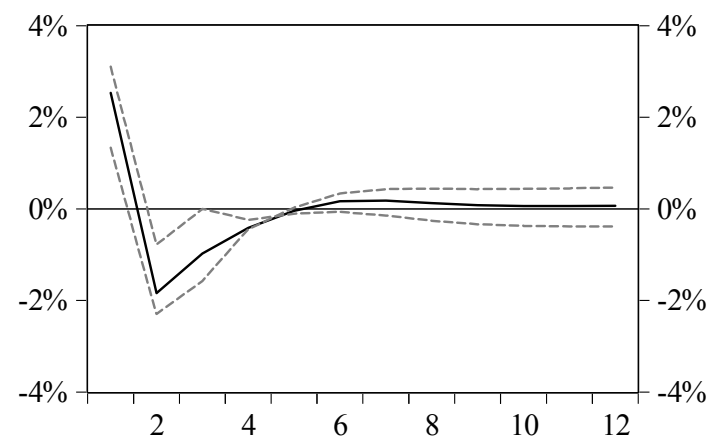

Response of D(FXRATE) to D(CPI)

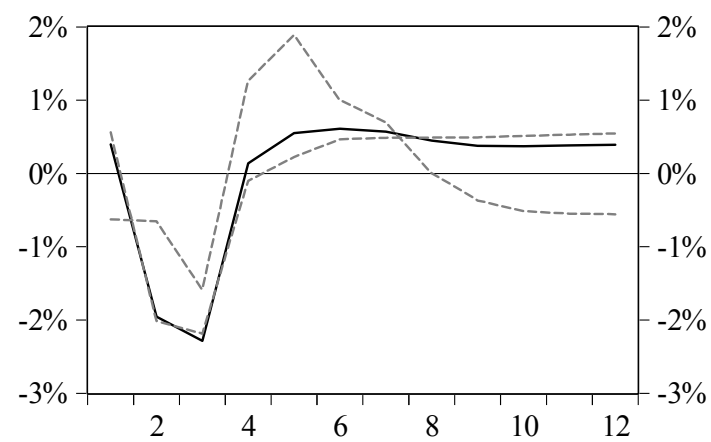

Figure 8: Impulse Response Functions of changes in FX, M1, M4, and CPI Data source: CNB 2014, calculation: E-Views 7.2.

lagged one month behind the inflation rate change, confirming our hypothesis that the CNB is targeting the monthly changes in the inflation rate, i.e. a moving target.

A currency peg gives a stable benchmark for the inflation rate. The surplus inflation over and above the eurozone inflation rate is then attributable to changes in relative prices. If the productivity growth is primarily in the internationally traded goods sector, the prices of tradables have to fall relative to the prices of nontradables. According to the Balassa-Samuelson effect, with fixed exchange rates the prices of non-tradables will have to rise.

The CNB classifies its newly officially proclaimed FX policy as a managed float (CNB 2014). Nevertheless, the CNB acknowledges its commitment to pursue the multiple (heterodox) target policy (exchange rate and inflation targeting) as the best way to preserve low inflation rates. It is the CNB's constitutional obligation to pursue primarily the price stability target. Only once this goal has been fulfilled may the CNB pursue additional objectives. According to the $\mathrm{CNB}$, its interventions on the exchange market accrue for no more than $3 \%$ of the total transactions volume. The largest amount has been used in the operations of selling kuna for euros in an attempt to prevent an appreciation of the kuna. Only recently has the CNB intervened several times to buy the kuna in an attempt to prevent depreciation of the kuna (CNB 2013, CNB 2014).

Depreciations feed inflation expectations and risk premiums. A higher risk premium reduces the real rate of return on capital. This is detrimental to investment and growth. Croatia would be better off if it could eliminate this negative and partially self-sustaining effect. But even without high exchange rate passthrough, a fixed exchange rate could be an optimal monetary policy in an environment of region-specific shocks (Devereux 2003).

Countries with difficulties in controlling their money supply benefit from a currency board/monetary union because the money supply is the primary Granger cause of inflation. This is also the Croatian case where Granger causality test results show best values between growth of M1 and inflation. Nevertheless, confidence in the domestic currency may depend on factors other than the exchange rate regime such as central bank independence (Cukierman, Miller, and Neyapti 2002), the degree of the openness of the economy and the level of debt and its sustainability because of its inherent incentive to monetize (Romer 1993, Romer 1998, Terra 1998). These are some of the issues worth future research. 


\section{CONCLUSION}

The goal of the paper was to test three statements made by the Croatian National Bank regarding its long term FX policy commitments, which are also often used by a number of other European central banks. The results of our econometric analysis show that the monthly weighted average kuna/euro FX rate is trend stationary, i.e. without a statistically significant trend, normally distributed and with homoscedastic residuals after modelling. To test the three hypotheses proposed by the CNB, it was also necessary to use the quarterly differentiated data of $\mathrm{FI}, \mathrm{FX}, \mathrm{M} 1, \mathrm{M} 4$, and CPI. To test the effectiveness of interventions, nominal FX and intervention data were tested for Granger causality. Following the results of time series stability analysis, the statement of FX rate stability cannot be rejected. It seems that the CNB indirectly pursues the goal set in the statement about not determining a priori boundaries or intervention points by directly pursuing the goal set in the statement about maintaining the stability of kuna/euro FX rate changes. The upper and lower intervention points may be generalized as FX rates' first differences. Since the CNB defends no nominal FX rate, but maintains its rate of change at \pm $1.9 \%$ per month, the second hypothesis of no upper and lower bounds of nominal FX rate returns can be rejected. A Granger causality test confirms the bidirectional causation effects between FX rate and interventions. The FX rate change is an important trigger of intervention. The results show that for Croatia kuna/euro FX rate stability is not a direct mechanism of price stability. The Granger causality test shows that the CNB cannot directly target inflation via FX rate. Johansen co-integration tests do not show any expected cointegrating vectors between the analyzed variables, and the cross-correlation tests do not show any significant direct pass-through effects between the FX rate and inflation as stated by the CNB.

We find that there is not enough statistical evidence for the confirmation of at least one out of three statements put forward by the CNB and which are usually considered absolutely correct and often serve as a starting point for fiscal/monetary policy decision-making. Nevertheless, we find a good political reason to change the official policy from free float to managed float: prospective EMU accession. Our FX rate model shows that the kuna/euro FX rate follows a very narrow currency peg of 7.44 kuna/euro with a coefficient of variation at $1.9 \%$, so even this policy change may be assessed as too moderate, as it clearly is a functional currency peg or a quasi-currency board as it is sometimes also called. As already stated, a firmer FX policy commitment toward the euro may be the only policy choice for the future. Small open economies such as Croatia that joined the EU and enjoy full freedom of capital movement are confronted with a classic policy trilemma that becomes the dilemma of whether to fix or to float because of the inability of choosing capital controls. It seems the CNB has anchored, although without a strong commitment. The recent statement change is probably just one more step towards the EMU.

\section{REFERENCES}

Box, G. E. P., Jenkins, G. M., Reinsel, G. C. 2008. Time Series Analysis: Forecasting and Control. New York: John Wiley \& Sons.

Buiter, W. H., Grafe, C. 2002. Anchor, Float or Abandon Ship: Exchange Rate Regimes for Accession Countries.' CEPR Discussion Paper, No. 3184, January, Centre for Economic Policy Research.

Calvo, G. A., Reinhart, C. M. 2000. Fear of Floating. NBER Working Paper No. 7993. http://www.nber.org/papers/ w7993 (accessed July 21, 2014).

CBD 2014. Croatian bureau of statistics internet site: http:// www.dzs.hr (accessed July 15, 2014).

Choudhri, E., Hakura,D., 2001. Exchange rate pass-through to domestic prices: Does the inflationary environment matter? IMF working paper 194(1). http://www.imf.org/ external/pubs/ft/wp/2001/wp01194.pdf (accessed July 10, 2014)

CNB 2013. Croatian National Bank internet site: http://www. hnb.hr (accessed September 7, 2013)

CNB 2014. Croatian National Bank internet site: http://www. hnb.hr/tecajn/etecajn.htm (accessed July 15, 2014)

Cukierman, A., Miller, G. P., Neyapti, B. 2002. Central bank reform, liberalization and inflation in transition economies: an international perspective. Journal of Monetary Economics 49(2): 237-264.

CZNB 2014. Czech National Bank official internet site: https://www.cnb.cz (accessed July 15, 2014).

Devereux, M. B. 2003. A Macroeconomic Analysis of EU Accession under Alternative Monetary Policies. Journal of Common Market Studies 41(5): 941-964.

Devereux, M. B., Engel, C. 2003. Monetary Policy in the Open Economy Revisited: Exchange Rate Flexibility and Price Setting Behaviour. Review of Economic Studies 70(4): 765-783.

Devereux, M. B. Lane, P. R. 2003. Understanding Bilateral Exchange Rate Volatility. Journal of International Economics 60:109-132.

Enders, W. 2010. Applied Econometric Time Series. New York: John Wiley \& Sons.

Engle, R. F., Granger, C. W. J. 1987. Co-integration and Error Correction: Representation, Estimation, and Testing. Econometrica 55(2): 251-76. 
Erjavec, N., Cota, B., Jakšić, S. 2012. Sources of Exchange Rate Fluctuations: Empirical Evidence from Croatia. Privredna kretanja i ekonomska politika 22(132): 27-47.

Friedman, M. 1963. Inflation: Causes And Consequences. New York: Asia Publishing House.

Friedman, M., Mundell, R. 2001. One world, one money? Policy Options / Options Politiques 10-30. http://web. ntpu.edu.tw/ guan/courses/Friedman-Mundell.pdf (accessed July 21, 2014).

Gagnon, J., Ihrig, J., 2004. Monetary policy and exchange rate pass-through. International journal of finance and economics 9: 315-338.

Granger, C. W. J. 1969. Investigating Causal Relations by Econometric Models and Cross-spectral Methods. Econometrica 37(3): 424-438.

Johansen, S. 1991. Estimation and Hypothesis Testing of Cointegration Vectors in Gaussian Vector Autoregressive Models. Econometrica 59(6): 1551-1580.

Maddala, G. S. 2001. Introduction to Econometrics. New York: John Wiley \& Sons.

Mihaljek, D., Klau, M. 2008. Exchange rate pass-through in emerging market economies: what has changed and why? Bank for International Settlements. http://www.bis. org/publ/bppdf/bispap35d.pdf (accessed July 28, 2014).

Mohanty, M. S., Berger, B. 2013. Central bank views on FX intervention. Bank for International Settlement, BIS Papers No 73:55-72. http://www.bis.org/publ/bppdf/bispap73. pdf (accessed July 8, 2014).
Mundell, R. 1961. A Theory of Optimum Currency Areas. American Economic Review November 509-517.

Posedel, P. 2006. Analiza tečaja i vrednovanje opcija na tečaj na hrvatskom tržištu: NGARCH model kao alternativa modelu Blacka i Scholesa. Financijska teorija i praksa 30(4): 345-367.

Romer, D. 1993. Openness and Inflation: Theory and Evidence. Quarterly Journal of Economics 108(3): 869-903.

Romer, D. 1998. A new assessment of openness and inflation: reply. Quarterly Journal of Economics 113(2): 649-652.

Schadler, S., Drummond, P., Kuijs, L., Murgasova Z., Elkan, R. 2004. Adopting the Euro in Central Europe: Challenges of the Next Step in European Integration. IMF, Occasional Paper 234.

Stučka, T. 2004. The Effects of Exchange Rate Change on the Trade Balance in Croatia. IMF Working Paper, WP 04/65.

Terra, C. 1998. Openness and Inflation: A New Assessment. Quarterly Journal of Economics 113(2): 641-648.

Tica, J., Posedel, P. 2009. Threshold Model of the Exchange Rate Pass-Through Effect. Eastern European Economics 47(6): 43-59.

Zivot, E., Andrews, D. W. K. 1992. Further Evidence on the Great Crash, the Oil-Price Shock, and the Unit-Root Hypothesis. Journal of Business \& Economic Statistics 10(3): 251-270. 